\title{
KONSUL SUGIHARA CHIUNE A POLSCY ŻYDZI W KOWNIE W OKRESIE 1939-1940
}

olocaust, termin który pochodzi od greckiego holo-kautóō (całopalenie), był stosowany jako określenie dokonanej przez hitlerowców zagłady Żydów europejskich w czasie II wojny światowej. Japonia jako sojusznik Niemiec podczas wojny miała bardzo trudne zadanie ustosunkowania się do polityki Adolfa Hitlera wobec wyznawców judaizmu. Działo się tak, mimo iż antysemityzm pojawił się w Japonii jeszcze przed urośnięciem w siłę nazizmu w Niem$\mathrm{czech}^{2}$. Dlatego też mimo prowadzonej przez władze Trzeciej Rzeszy przed wybuchem II wojny światowej propagandy antyżydowskiej również w Japonii, kraj ten nigdy nie poparł działań swojego sojusznika w kwestii eksterminacji narodu żydowskiego.

W 1936 roku w Berlinie podpisany został między Japonią a Niemcami tak zwany pakt antykominternowski, który miał być układem dotyczącym walki z działaniami Kominternu, czyli Międzynarodówki Komunistycznej. Do pierwszych rozmów w sprawie tego układu doszło zaraz po tym, jak podczas VII Kongresu Międzynarodówki Komunistycznej (sierpień 1935 roku) nazwano zachowanie Japonii i Niemiec działaniem „podżegaczy wojennych”. Zarówno w Tokio, jak i w Berlinie uznano, że znacznie wygodniejsze będzie wyjście poza tradycyjną formułę bilateralnego układu

$\bullet \bullet \bullet \bullet \bullet \bullet \bullet \bullet \bullet \bullet \bullet \bullet \bullet \bullet \bullet \bullet \bullet \bullet \bullet \bullet \bullet \bullet \bullet \bullet \bullet \bullet \bullet$

Mgr Olga BARBASIEWICZ, japonista i kulturoznawca, obecnie jest związana ze Szkołą Wyższą Psychologii Społecznej w Warszawie. obarbasiewicz@gmail.com

W. Kopaliński, Stownik wyrazów obcych i zwrotów obcojęzycznych, wyd. XVII, Państwowe Wydawnictwo Wiedza Powszechna, Warszawa 1967.

2 G. Krebs, The „Jewish Problem” in Japanese-German Relations, 1933-1945, [w:] Japan in the Fascist Era, ed. E. Bruce Reynolds, Palgrave MacMillan, New York 2004, s. 107. 
politycznego i podkreślenie ogólnych celów walki z komunizmem międzynarodowym, co mogło łagodzić obawy państw zachodnich i jednocześnie czynić układ otwartym dla innych ${ }^{3}$. Jesienią 1937 roku do tego układu dołączyły Włochy, a w lutym 1938 roku Adolf Hitler, zaniechawszy myśli o rozległej misji militarnej w Chinach, publicznie poparł japońskie „działania antykomunistyczne”, jednocześnie uznając w maju tego samego roku istnienie państwa Mandżukuo4.

Władze w Tokio traktowały to sprzymierzenie się z władzami niemieckimi jako m.in. przeciwdziałanie nieprzyjaznej polityce Związku Radzieckiego wobec Japonii. Gdy w 1938 roku Konoe Fumimaro, pełniący funkcję premiera od 1937 roku, powołał na stanowisko ministra spraw zagranicznych Aritę Hachirō, ten popierał układ japońsko-niemiecki, jednak nie uważał go za instrument, za pomocą którego można byłoby zmienić układ sił w regionie Azji i Pacyfiku na niekorzyść Europejczyków i Amerykanów55. 22 maja 1939 roku Włochy i Trzecia Rzesza podpisały tak zwany pakt żelazny, jednak gdy 23 sierpnia 1939 roku zawarty został niemiecko-radziecki traktat o nieagresji, czyli pakt Ribbentrop-Mołotow, nie tylko Mussolini odczuł niepokój. Również w Japonii pojawiła się obawa o skutki takiego sojuszu, gdyż odebrany on został jako zdrada ze strony Niemiec, z którymi od ponad roku prowadzono negocjacje w sprawie układu wojskowego 6 .

Jednocześnie w lipcu tego roku, poprzez decyzję Franklina Roosevelta, nie został odnowiony bilateralny układ z 1911 roku między Japonią a Stanami Zjednoczonymi, dotyczący handlu i żeglugi. Działanie to umożliwiło Stanom Zjednoczonym nałożenie sankcji ekonomicznych na Japonię. Był to punkt zwrotny w polityce japońskiej. W tej sytuacji rząd Japonii zdecydował się zwrócić w stronę Niemiec, rezygnując z prób pozyskania sojusznika w postaci Stanów Zjednoczonych.

Gdy po wybuchu wojny w Europie, Trzecia Rzesza odnosiła sukcesy militarne kolejno we Francji, Belgii i Holandii, Japonia zdecydowała się dołączyć do Osi Berlin-Rzym. 27 września 1940 roku podpisane zostało trójstronne porozumienie między Niemcami, Włochami i Japonią. Niemcy reprezentował Joachim von Ribbentrop, Włochy - Galeazzo Ciano, a Japonię ówczesny ambasador Japonii w Berlinie Kurusu Saburō. Trzy państwa połączył podobny punkt widzenia na konieczność ustanowienia nowego porządku na obu kontynentach.

Po zawarciu tego układu rząd japoński był zachęcany przez władze Trzeciej Rzeszy do prowadzenia na swoim terenie polityki antyżydowskiej. Jednak japoński rząd odmówił. Minister spraw zagranicznych Japonii Matsuoka Yōsuke powiedział w tym czasie, zwracając się do rządu Trzeciej Rzeczy:

„Po pierwsze chciałbym oświadczyć, że antysemityzm nie zostanie nigdy zaakceptowany przez Japonię. To prawda, zawarłem traktat z Hitlerem, jednak nigdy nie obiecywałem bycia antysemitą. I nie jest to jedynie moja osobista opinia, a stanowisko całego Cesarstwa Japonii"”.

Matsuoka posunął się przy tym do stwierdzenia, że jeśli Niemcy dopuszczą się kiedykolwiek żądań wobec Japonii dotyczących eksterminacji Żydów, Japonia prędzej zerwie sojusz, niż dopuści się takich działań8. Konsekwencją takiej polityki rządu japońskiego .....

E. Pałasz-Rutkowska, Polityka Japonii wobec Polski 1918-1941, Wydawnictwo Nozomi, Warszawa 1998, S. 95-96.

S. Giffard, Japan among the Powers, Yale University Press, New Haven \& London 1994, s. 106.

Ibid., s. 107

E. Pałasz-Rutkowska, Polityka..., op. cit., s. 99-100.

Y. Sugihara, Visas for Life, Taishō Shuppan, Tōkyō 1993, s. 55

Ibid., s. 55-56. 
było pozwolenie na zasiedlenie przez Żydów obszaru na terenie okupowanego przez Japonię Szanghaju.

W 1931 roku po tak zwanym incydencie mandżurskim pod kontrolę władz japońskich dostali się Żydzi rosyjscy, mieszkający w Mandżurii po zesłaniu przez władze Związku Radzieckiego. Ta grupa, licząca około 10000 wyznawców judaizmu, spotykała się z atakami rosyjskich grup przestępczych, które często współpracowały z japońską tajną policją i Rosyjską Partią Faszystowską. Z uwagi na takie incydenty, organizacje żydowskie wystąpiły do rządu japońskiego z prośbą o ochronę. W związku z tym w 1937 roku na terenie Mandżukuo powstała Narodowa Rada Wspólnot Żydowskich na Dalekim Wschodzie (Kyokutō Yudaya Minzoku Kaigi) ${ }^{10}$. Organizacja ta w latach 1937-1939 miała swoje przedstawicielstwo w Harbinie. Rząd japoński widział w takiej współpracy z Żydami szansę naprawienia stosunków Japonii ze Stanami Zjednoczonymi, z uwagi na znaczną rolę, jaką w tym kraju odgrywali obywatele pochodzenia żydowskiego.

Jak wcześniej wspomniano, dobre relacje japońsko-żydowskie próbowali popsuć niemieccy politycy. Książka Mein Kampf autorstwa Hitlera, w której twierdził on, że odpowiedzialność za zniszczenie Niemiec w trakcie I wojny światowej ponoszą właśnie Żydzi, którzy pragną stworzyć światowe mocarstwo ${ }^{11}$, została przetłumaczona w 1937 roku na język japoński. Hitler pisał w niej również, że sojusz żydowsko-bolszewicki ma na celu osiągnięcie dominacji w Europie i Stanach Zjednoczonych, a jedynym narodem, który może powstrzymać taki postęp rzeczy jest Japonia. Przetłumaczona w 1938 roku książka Der Mythus des 20. Jahrhunderts autorstwa Alfreda Rosenberga również zawierała treści antyżydowskie w kontekście japońskim². Autor pisał w niej o „konspiracji żydowskiej" spiskującej przeciwko Japonii. Jednak nawet takie działania nazistowskiej propagandy nie skłoniły Japonii do zmiany polityki wobec narodu żydowskiego, co wywołało wśród niemieckiej opinii ogrom zarzutów.

Gdy po aneksji Austrii, dokonanej w listopadzie 1938 roku, rząd niemiecki rozpoczął pogromy ludności żydowskiej, spowodowało to ogromne fale emigracji13. Japonia nie chciała zwracać uwagi Żydów na terytoria będące pod panowaniem japońskim, jednak nie popierała polityki hitlerowskich Niemiec, która godziła w zasadę państwa japońskiego mówiącą o traktowaniu wszystkich ras z jednakowym szacunkiem. Równocześnie zamiarem Japonii była poprawa stosunków ze Stanami Zjednoczonymi, które mogły się okazać idealnym inwestorem zagranicznym na ziemiach chińskich, będących pod kontrolą japońską. Poprawa taka mogła - zdaniem Japończyków - nastąpić dzięki pozytywnemu nastawieniu Tokio wobec Żydów. Z tego też powodu Żydzi powinni być traktowani tak samo jak obywatele każdego państwa.

Jednak japońscy dziennikarze promowali wśród obywateli tego kraju nastroje antysemickie. Szczególnie aktywni byli publicyści dziennika „Mainichi Shimbun”. Gloryfikował on nazistowską ideologię i winił Żydów za wywoływanie wojen ${ }^{14}$. W 1938 roku "Mainichi Shimbun" zorganizował pod patronatem ministra spraw zagranicznych Niemiec Joachima von Ribbentropa i ministra propagandy Josepha Goebbelsa wystawę poświęconą „Wielkim Niemcom”, a w latach 1942-1943 liczne sympozja i wystawy dotyczące związ-

11 A. Hitler, Mein Kampf, ttum. na angielski James Murphy, Hurst \& Blackett Ltd., London - New York - Melbourne 1939, s. 352.

12 G. Krebs, The "Jewish Problem”..., op. cit., s. 110.

13 Ibid., s. 113.

14 Ibid., s. 120 
ków Żydów i masonerii. Ta działalność propagandowa w Japonii była w całości finansowana przez ambasadę niemiecką.

Gdy w 1943 roku w Hongkew (dzielnicy Szanghaju), stworzona została strefa wydzielona dla Żydów, określana była często mianem „getta”15. Działo się tak, gdyż mieszkający w Szanghaju Żydzi musieli się wprowadzić do tej strefy do 18 maja 1943 roku, otrzymując jednocześnie zakaz poruszania się poza granicami tego obszaru. Żydowscy mieszkańcy Szanghaju byli w rzeczywistości uciekinierami z europejskich krajów, takich jak Polska, Niemcy, Austria, Czechosłowacja czy kraje bałtyckie. Uciekinierzy ci wybierali na miejsce pobytu Szanghaj. Był on miastem, do którego podczas wjazdu nie potrzeba było posiadać wizy z uwagi na jego międzynarodowy status, ustanowiony na mocy amerykańsko-chińskiego traktatu z Wangxia z 1844 r. ${ }^{16}$ Zarządzeniem o przesiedleniu do Hongkew nie zostali objęci radzieccy Żydzi, gdyż pojawili się oni w Szanghaju jeszcze przed 1937 roku, a ponadto byli obywatelami kraju zachowującego neutralność wobec wojny na Pacyfiku, zaś rząd w Tokio zamierzał uniknąć wszelkich działań mogących być uznane za prowokacje wobec Związku Radzieckiego.

Gdy w 1940 roku Benito Mussolini przystąpił do wojny w Europie, niemożliwa stała się podróż z Europy do Szanghaju włoskimi parowcami regularnie obsługującymi tę linię ${ }^{17}$. W tym momencie jedyną drogą ucieczki dla europejskich Żydów okazała się Kolej Transsyberyjska.

\section{SYLWETKA SUGIHARY CHIUNE (1900-1986)}

\section{LATA MŁODOŚCI I ŻYCIE RODZINNE}

Sugihara Chiune urodził się 1 stycznia 1900 roku w Yaotsu, małym mieście położonym w prefekturze Gifu. Data urodzenia uważana była przez Sugiharę za piętno, gdyż jak sam twierdził, należał do tych, którzy ugrzęźli między dwiema epokamii"

Rodzicami przyszłego konsula byli Sugihara Yatsu i Yoshimi. Rodzina matki szczyciła się pochodzeniem od lokalnego księcia feudalnego. Oprócz rodowodu matka przyszłego konsula odznaczała się niezwykłą urodą. Mimo to zdecydowała się wyjść za człowieka pochodzącego z niższej klasy społecznej. Rodzina Sugihary nosiła nazwisko Iwai. Jak głosi rodzinna legenda, ojciec Chiune podczas odbywania służby wojskowej w Mandżurii i na Syberii zachorował na gruźlicę. Lekarzem, który opiekował się nim i doprowadził do wyleczenia, był Sugihara Kōsui. Pacjent w dowód wdzięczności wyraził chęć zostania adoptowanym synem lekarza. Propozycja została przyjęta, a ojciec Chiune przyjął nazwisko Sugihara ${ }^{19}$. Gdy po powrocie w rodzinne strony otworzył firmę dostarczającą przesyłki pocztowe, uznał, że łatwiej mu będzie prowadzić interesy, posługując się nazwiskiem swojego przybranego ojca. Od tej pory rodzina Chiune zaczęła posługiwać się nowym nazwiskiem.

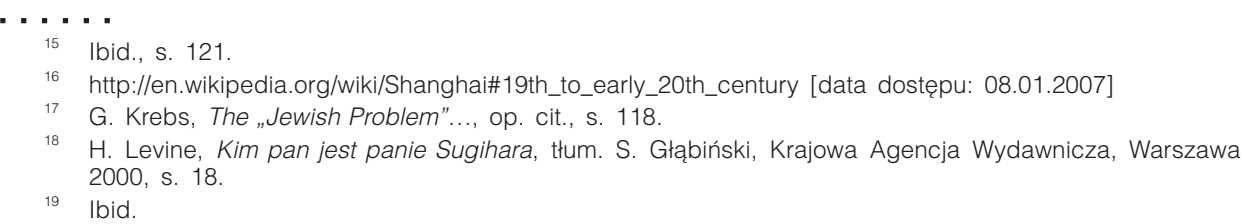


Dzieciństwo Sugihary Chiune przypadło na okres, gdy Japonia, pokonując Rosję zarówno na lądzie, jak i na morzu, udowodniła światu, że w pełni dojrzała do roli partnera - rywala mocarstw na Dalekim Wschodzie ${ }^{20}$. Nie musiał pracować tak jak większość dzieci z jego rodzinnego miasta przy uprawie pól ryżowych, dlatego miał dużo wolnego czasu. Jak opisuje Hillel Levine na podstawie wywiadu z siostrą Sugihary, Nakamurą Ryuko, z 6 lipca 1994 roku, ,już w wieku pięciu lat Chiune miał szerokie bary i był silny. Potrafił pływać i z powodzeniem współzawodniczył ze starszym o trzy lata bratem. Lubił łowić ryby, a po południu przed powrotem do domu piekł je w ognisku"21. Czas, w którym przypadło Sugiharze dorastać, był okresem gwałtownej modernizacji i przyswajania wzorów z Zachodu, przy jednoczesnym wpajaniu młodemu pokoleniu zasad, które mówiły o tym, że pokonanemu należy zawsze okazywać szacunek i współczucie ${ }^{22}$. Takie wychowanie miało z pewnością ogromny wpływ na dalsze postępowanie Sugihary Chiune.

Kiedy ojciec Sugihary otrzymał pracę poborcy podatkowego, rodzina była zmuszona do częstych przeprowadzek. W 1907 roku siedmioletni Chiune przeniósł się z rodzicami do Kuwany w prefekturze Mie, a następnie powrócił do prefektury Gifu, skąd w 1909 roku przeprowadził się do Nagoi, w prefekturze Aichi²3. To właśnie w tym mieście w 1912 roku Sugihara ukończył z wyróżnieniem szóstą klasę w szkole Furuwatari24, by rozpocząć edukację w gimnazjum w Nagoi ( Daigo Chūgaku), którą ukończył w 1917 roku²5. W tym czasie ojciec Sugihary przebywał już w Korei, anektowanej przed Japonię w 1910 roku; pełnił tam funkcję urzędnika administracji kolonialnej. Po ukończeniu szkoły średniej Sugihara zdał egzaminy na Uniwersytet Waseda i rozpoczął studia na Wydziale Anglistyki. Jednak z powodów materialnych nie mógł ich ukończyć i w 1919 roku został skreślony z listy studentów ${ }^{26}$

Mimo nieukończenia studiów w Tokio, Sugihara Chiune postanowił przystąpić do egzaminów w Ministerstwie Spraw Zagranicznych. Zdał je na tak dobrym poziomie, że otrzymał stypendium Ministerstwa i 6 października 1919 roku rozpoczął naukę na Wydziale Rusycystyki uczelni działającej przy Towarzystwie Japońsko-Rosyjskim (Nichiro Kyōkai Gakkō)27, która następnie została przekształcona w Harubin Gakuin (Instytut Harbiński).

Również małżeństwo z Klaudią (Kławdiją) Siemionowną Apołłonową nie pozostało bez znaczenia dla kształtowania się kariery dyplomatycznej Sugihary Chiune. Na pytanie, dlaczego Sugihara wolał żonę Rosjankę od żony Japonki, w wywiadzie, którego Klaudia Apołłonowa udzieliła Lewinowi, była żona Chiune stwierdziła, że „on kocha Rosjan. Rozumie ich"28. Sugihara Chiune przeszedł w tym okresie na wiarę prawosławną, otrzymując podczas chrztu imiona Siergiej Pawłowicz. Rosyjskie imię Siergiej kojarzyło się popowi z wymową nazwiska przyszłego konsula, natomiast otczestwo utworzone zostało od imienia Paweł, które nosił ów duchowny prawosławny ${ }^{29}$.

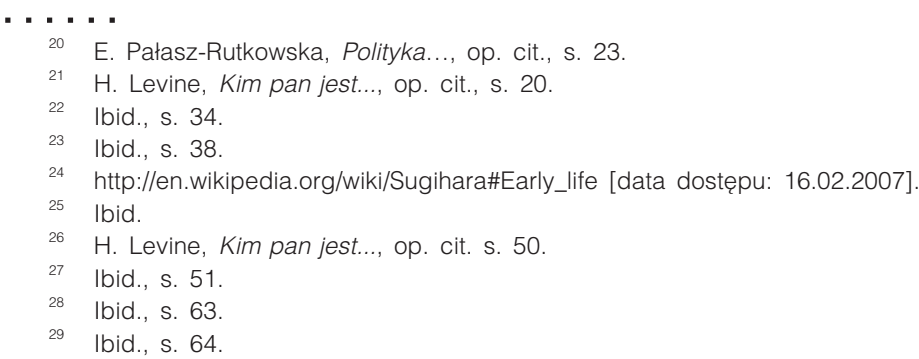


Ojciec Klaudii, Siemion Apołłonow, był najprawdopodobniej strażnikiem na Kolei Południowomandżurskiej ${ }^{30}$. Cieszył się sympatią swojego zięcia, który często go odwiedzał¹. Takie stosunki dawały możliwość pozyskiwania obustronnych informacji, gdyż nie tylko Sugihara zdobywał wiadomości od swojego teścia. Również Siemion Apołłonow został przez swoje koneksje rodzinne wprowadzony do japońskiej administracji kolonialnej32. Obraz Sugihary wyłaniający się z wypowiedzi jego pierwszej żony podczas wywiadu z Levinem jest następujący: „Mąż był bardzo dobry dla ludzi i zwierząt. Lubił wszystkich, Żyd nie Żyd. W każdym widział przyjaciela. Był wykształcony. Nim mnie spotkał, studiował w Moskwie na tamtejszym uniwersytecie. Był przyjazny wobec wszystkich"33.

W 1935 roku Klaudia Apołłonowa i Sugihara Chiune rozwiedli się za porozumieniem stron $^{34}$. Przyczyny tego rozwodu nie są do końca jasne, wiadome jest jednak, że byli małżonkowie utrzymywali ze sobą kontakt aż do 1981 roku $^{35}$.

W tym samym roku Sugihara wszedł w ponowny związek małżeński. Jego wybranką był tym razem Japonka, Kikuchi Yukiko. Dziewczyna była o 14 lat młodsza od Chiune, dlatego w swoim pamiętniku pisała: „Małżeństwo ze starszym człowiekiem mogło zapewnić mi więcej bezpieczeństwa niż z kimś młodszym" ${ }^{36}$. Ze związku z Yukiko Sugihara doczekał się czterech synów, z których jeden, trzeci z kolei - Haruki, zmarł w 1947 roku tuż po powrocie rodziny do Japonii ${ }^{37}$. W 1990 roku, cztery lata po śmierci męża, Sugihara Yukiko opublikowała pamiętnik, w którym opisała wydarzenia mające miejsce w Kownie. Książka ta, nosząca tytuł Rokusennin-no inochi-no biza, ukazała w sposób niezwykle precyzyjny wydarzenia z 1940 roku.

\section{KARIERA DYPLOMATYCZNA (1919-1947)}

Początek kariery dyplomatycznej Sugihary Chiune związany był z jego wstąpieniem do wcześniej wspomnianej uczelni przy Towarzystwie Japońsko-Rosyjskim. Podczas studiów na Wydziale Rusycystyki Sugihara Chiune uczył się języka rosyjskiego oraz niemieckiego, aby później stać się specjalistą od stosunków ze Związkiem Radzieckim ${ }^{38}$.

Mimo że w 1920 roku Sugihara otrzymał stypendium umożliwiające kontynuację studiów, w październiku tego samego roku został powołany do odbycia służby wojskowej39. Odbywał ją w 79. Pułku Piechoty, stacjonującym niedaleko miasta, w którym mieszkali rodzice Chiune - Seulu4 ${ }^{40}$ W 1921 roku Sugihara awansował do stopnia podporucznika ${ }^{41}$, a w 1922 roku po zwolnieniu ze służby powrócił do Harbinut2.

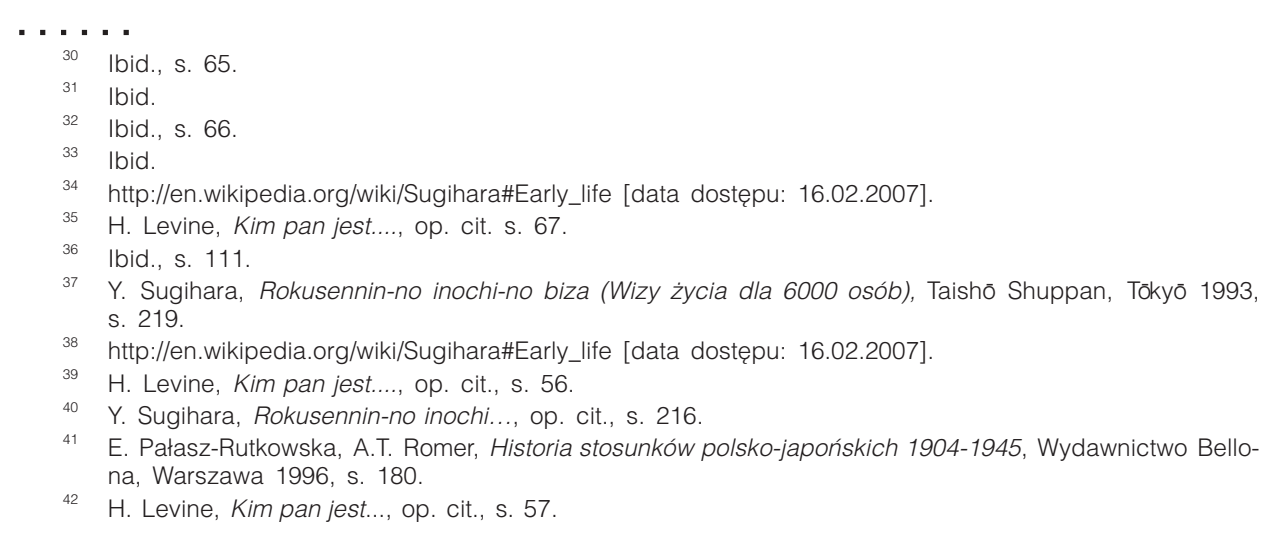


Rok po odejściu do rezerwy Sugihara kontynuował naukę w uczelni przy Towarzystwie Japońsko-Rosyjskim. W 1924 roku, po ukończeniu specjalnego kursu, został zatrudniony jako praktykant w Ministerstwie Spraw Zagranicznych w konsulacie generalnym Japonii w Harbinie ${ }^{43}$. W 1929 roku Sugihara rozpoczął pracę w Nichiro Kyōkai Gakkō, gdzie wykładał gramatykę języka rosyjskiego oraz sprawy polityczne i gospodarcze Związku Radzieckiego ${ }^{44}$. Wkrótce po proklamowaniu niepodległości Mandżukuo w 1932 roku Sugihara Chiune wyjechał w podróż służbową do Changchunu; w 1934 roku został dyrektorem Wydziału Polityki Zagranicznej Mandżukuo, skąd został odwołany rok później, aby z kolei podjąć pracę w MSZ Japonii45. Od tego momentu kariera dyplomatyczna Sugihary zaczęła się rozwijać w bardzo szybkim tempie.

W 1933 roku rząd Związku Radzieckiego, w obawie przed rozszerzeniem działań Armii Kwantuńskiej poza Mandżurię, wystąpił do rządu Japonii z propozycją paktu o nieagresji. Z drugiej strony nie rezygnował z powiększenia liczby swoich wojsk na Dalekim Wschodzie ${ }^{46}$. Strona japońska nie przyjęła tej propozycji, jednak zgodziła się zostać mediatorem i gwarantem finansowym w rozmowach między ZSRR a Mandżukuo, które dotyczyły sprzedaży Kolei Południowomandżurskiej ${ }^{47}$. W tych pertraktacjach ważną funkcję pełnił Sugihara, który jako asystent wiceministra spraw zagranicznych pomagał w zbieraniu informacji. Jak wcześniej zostało wspomniane, pracownikiem Kolei był jego ówczesny teść, Siemion Apołłonow, co znacznie ułatwiało wypełnianie obowiązków służbowych Sugiharze. Zbierane przez niego informacje dotyczyły m.in. położenia wagonów kolejowych wycofanych przez Rosjan na Syberię. Dzięki nim rząd w Tokio mógł prowadzić negocjacje ze stroną radziecką na temat redukcji ceny, jakiej żądali Rosjanie za sprzedaż kolei ${ }^{48}$. Do porozumienia doszło w 1935 roku i od tego momentu Japończycy stali się jedynymi użytkownikami Kolei Południowomandżurskiej.

W 1936 roku Sugihara otrzymał rozkaz wyjazdu do Moskwy jako II sekretarz-łłumacz ambasady Japonii. Jednak ze strony ZSRR został zgłoszony sprzeciw, w związku z czym Chiune udał się wraz z żoną Yukiko do stolicy Finlandii - Helsinek. To właśnie w tym mieście Sugihara dowiedział się o wybuchu II wojny światowej w Europie.

Pod koniec 1939 roku rząd japoński ustanowił nową placówkę dyplomatyczną w Kownie, wysyłając do niej jako wicekonsula Sugiharę Chiune ${ }^{49}$. W litewskim konsulacie Sugihara nawiązał kontakt z polskim wywiadem, a następnie wydał wizy, dzięki którym Żydzi polskiego, litewskiego i niemieckiego pochodzenia mogli udać się Koleją Transsyberyjską do Japonii, uciekając przed zagładą, jaką niosły ze sobą wojska hitlerowskie. Po zamknięciu placówki na Litwie Sugihara wyjechał do Pragi, a następnie do Królewca, gdzie od marca 1941 roku pełnił funkcję zastępcy konsula generalnego. W tym samym roku został oddelegowany jako III sekretarz-tłumacz do poselstwa Japonii w Rumunii. W 1945 roku trafił do radzieckiego obozu jenieckiego w okolicach Bukaresztu. Po zwolnieniu wraz z rodziną wrócił do Japonii Koleją Transsyberyjską. W 1947 roku został zwolniony z Ministerstwa Spraw Zagranicznych w Tokio.

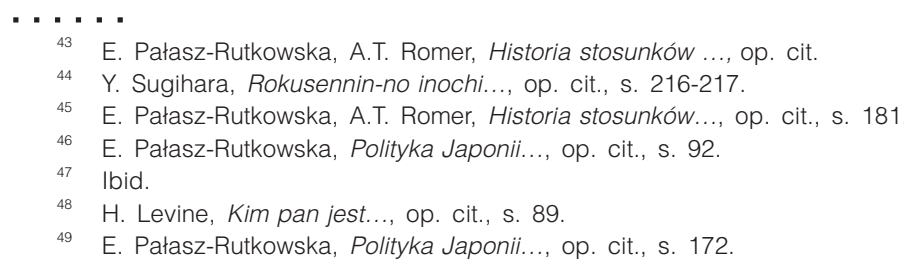


Po wybuchu II wojny światowej Japończycy kontynuowali rozpoczętą za czasów II Rzeczypospolitej współpracę z polskim wywiadem. Japońskiemu rządowi trudno było prowadzić wywiad w Europie ze względu na sojusz z III Rzeszą. Ponieważ nie posiadali dostatecznego zaufania do swojego sojusznika, w celu pozyskania dokładnych informacji na temat sytuacji na tym terenie zobowiązali się do współpracy z Polakami. Wywiad polski w zamian za przekazywane informacje otrzymał możliwość konspirowania swoich oficerów łącznikowych w japońskich placówkach dyplomatycznych w Niemczech, krajach nadbałtyckich i skandynawskich oraz przekazywania raportów wywiadowczych do Sztokholmu w japońskiej poczcie dyplomatycznej ${ }^{50}$.

Sugihara Chiune, który został wicekonsulem w nowo powstałej placówce w stolicy Litwy - Kownie, otrzymał od władz japońskich zadanie obserwacji zarówno strony niemieckiej, jak i radzieckiej51. W niepublikowanym rosyjskojęzycznym raporcie Sugihara tak opisał cel swojego pobytu na Litwie:

„Generał Ōshima (...) chciał się upewnić, czy rzeczywiście armia niemiecka wystąpi przeciw ZSRR. Chodziło między innymi o to, że w rychłym uderzeniu Niemiec na ZSRR z zachodu bardzo zainteresowany był japoński Sztab Generalny, który chciał jak najszybciej wycofać najlepsze siły Armii Kwantuńskiej, tj. armii japońskiej, stacjonującej w Mandżurii, z granicy mandżursko-radzieckiej i przerzucić je na wyspy południowe Oceanu Spokojnego. Szybkie i prawidłowe ustalenie terminu niemieckiej napaści było głównym zadaniem posła. Jasne stało się dla mnie, dlaczego Sztab nalegał na MZS, aby otworzyć konsulat w Kownie.

Będąc konsulem w Kownie, gdzie nie istniała kolonia japońska, zrozumiałem, że moim głównym zadaniem było informowanie Sztabu Generalnego oraz ministerstwa (...) o koncentracji wojsk niemieckich w pobliżu granicy $(\ldots)^{, 52}$.

Sugihara, który wiedział, że do współpracy niezbędni mu będą przedstawiciele polskiego wywiadu, zatrudnił za pośrednictwem podporucznika Ludwika Hryncewicza, Bolesława Różyckiego. Wiosną 1940 roku japoński konsul rozpoczął bliższą współpracę z kapitanem Alfonsem Jakubiańcem, pseudonim Jerzy (Żorż) Kuncewicz, i z porucznikiem Leszkiem Daszkiewiczem, posługującym się pseudonimem Jan Stanisław Perz ${ }^{53}$. Jak wspomina Jadwiga Ulvdaite w filmie Andrzeja Miłosza i Piotra Weycherta Wizy życia-czyli japoński szlak z litewskiej pułapki, Polacy i Sugihara byli nierozłączni. Bolesław Różycki z Janem Perzem spotykali się w domu Ulvdaite, zostawiali w nim różne paczki i pieniądze. Kobieta powiedziała kiedyś Bolesławowi Różyckiemu: „Pan tu, panie Bolesławie, nie dla Japonii pracuje. To Japończycy wam, Polakom, bardziej pomagają. To nie japońskie przedstawicielstwo tylko wasze, polskie" 54 .

Współpraca polskiego wywiadu i Sugihary była również związana z wydawaniem japońskich wiz tranzytowych dla polskich uchodźców, gdyż jak napisał w raporcie Daszkiewicz, konsul pozytywnie odpowiedział na propozycję, „by uchodźcy polscy mogli jechać tranzytem przez Rosję i Japonię do Ameryki i na jedną z wysp u brzegów Ameryki Południowej"55.

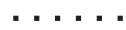

50 Ibid., s. 170

51 E. Pałasz-Rutkowska, T. Romer, Polish-Japanese Co-operation in World War II, [w:] „Japan Forum. The International Journal of Japanese Studies", t. $7 \mathrm{nr}$ 2/1995, Oxford University Press, Oxford, s. 287.

52 E. Pałasz-Rutkowska, A.T. Romer, Historia stosunków..., op. cit., s. 181.

53 E. Pałasz-Rutkowska, Polityka Japonii..., op. cit., s. 172-173.

54 Wizy życia - czyli japoński szlak z litewskiej pułapki, film dokumentalny, reż. A. Miłosz i P. Weychert, Grupa Filmowa Kontakt Agencja Produkcji Teatralnej i Filmowej TVP S.A., 1997.

55 E. Pałasz-Rutkowska, Polityka Japonii..., op. cit., s. 173. 
Po zakończeniu pełnienia funkcji wicekonsula w Kownie Sugihara wystawił Jakubiańcowi i Daszkiewiczowi jako sekretarzom konsulatu japońskie paszporty służbowe, dzięki czemu Daszkiewicz mógł towarzyszyć konsulowi w pełnieniu jego funkcji w Pradze i w Królewcu.

SUGIHARA A WYDARZENIA W KOWNIE W LATACH 1939-1940

POSTAWA RZĄDU JAPOŃSKIEGO WOBEC KWESTII WIZ

Sugihara Yukiko, druga żona konsula Sugihary Chiune, w swojej książce Visas for Life zamieściła wspomnienia dotyczące wydarzeń mających miejsce w Kownie w 1940 roku, których była świadkiem.

27 lipca 1940 roku Sugihara Chiune od około dziewięciu miesięcy pełnił funkcję wicekonsula w japońskim konsulacie w Kownie. W tym dniu przed budynkiem ustawiło się około stu lub dwustu osób czekających na spotkanie z Sugiharą5. Sugihara Yukiko wspomina, że był to niezwykły widok, gdyż ulica przed konsulatem była zazwyczaj pusta i cicha ${ }^{57}$.

„Zobaczyłam przed sobą setki ludzi kłębiących się w tłumie i innych, którzy właśnie nadchodzili. Głosy dochodzące z tłumu robiły się coraz głośniejsze. Ludzie wyglądali na wystraszonych, a nawet zdesperowanych. Byli głodni i brudni. Niektórzy z nich wspinali się na bramę. Panowat chaos" ${ }^{\prime \prime 8}$.

Ludzie, którzy znajdowali się przed bramą konsulatu, byli Żydami, głównie polskiego pochodzenia, przybyłymi do Kowna. Uciekali przed nazistami i chcieli prosić japońskiego konsula o wystawienie wizy. Otrzymanie takiego dokumentu pozwoliłoby im na ucieczkę z Europy, w której naziści wprowadzali w życie plan eksterminacji narodu żydowskiego.

Sugihara Chiune w swoich notatkach tak opisał tłum żydowskich uciekinierów:

„Ci ludzie szli przez wiele dni (...), doświadczając ogromnych cierpień. Ich celem było dotarcie do Kowna. Tym, co pragnęli osiągnąć, było otrzymanie z japońskiego konsulatu wiz tranzytowych, które umożliwiłyby im ucieczkę przed nazistami przez Związek Radziecki. Ci uchodźcy szli bez względu na pogodę. Niektórzy szli wzdłuż torów kolejowych (...), ci mający większe szczęście przybyli pociągiem"59.

Według wiadomości, jakie Yukiko zdobyła od Bolesława Różyckiego, osoby te chciały przedostać się przez Związek Radziecki do portu we Władywostoku, a stamtąd dalej do Japonii. Wizy wystawione przez zagraniczne przedstawicielstwo dyplomatyczne były jedyną szansą na ucieczkę przed prześladowaniami ze strony hitlerowskich Niemiec. Żydzi szukali pomocy w wielu miejscach, wszędzie jednak spotykali się z odmową. Szansą okazała się wiadomość, że konsulaty japoński i holenderski są w stanie wystawić wizy, dzięki którym możliwe jest dotarcie do holenderskiej kolonii Curaçao na Morzu Karaibskim ${ }^{60}$. Jednak nie można udać się tam w inny sposób niż przez Japonię. O fakcie tym Żydzi zostali poinformowani przez honorowego konsula holenderskiego Jana Zwartendijka, który jako jedyny wyraził chęć udzielenia pomocy. Kiedy uchodźcy

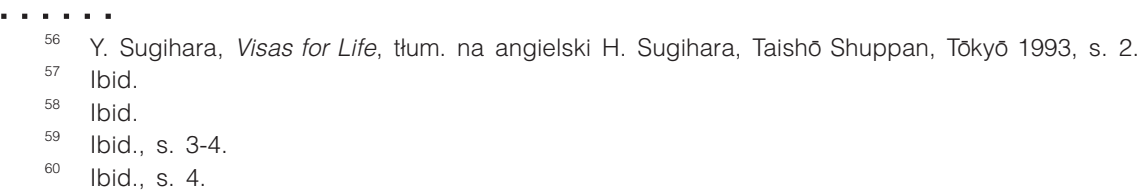


pojawili się przed konsulatem, w którym służbę pełnił Sugihara Chiune, ten musiał podjąć trudną decyzję. Obawiał się bowiem, że pomoc Żydom może zostać odebrana przez rząd niemiecki jako wrogi akt ze strony sojusznika, którym była Japonia ${ }^{61}$. Postąpić zgodnie z własnym sumieniem również nie było łatwo ze względu na to, że mogło to rzutować na dalsze losy całej rodziny konsula Sugihary.

Ostatecznie Sugihara zdecydował, że tłum nie może dłużej stać pod bramą konsulatu i poprosił pięciu Żydów, z Zorachem Warhaftigiem na czele, aby przedstawili mu swoją sytuację $^{62}$. Warhaftig zainicjował rozmowę na temat ciężkiej sytuacji, w jakiej znaleźli się żydowscy uciekinierzy i przez dwie godziny opowiadał o okrutnych losach polskich i niemieckich Żydów63. W pewnym momencie Warhaftig powiedział do Sugihary: „Przyszliśmy tu, ponieważ słyszeliśmy, że istnieje możliwość otrzymania wiz tranzytowych wydanych przez japoński konsulat. Prosimy więc pana o wystawienie dla nas wiz" 64 . Jak wspomina Sugihara Yukiko, Chiune wierzył ludziom, których wysłuchał, wiedząc jednocześnie, że nikt inny nie udzieli im oczekiwanej pomocy.

Pięciu reprezentantów przybyłych uchodźców zdawało sobie sprawę z tego, że konsulat japoński w najbliższym czasie zostanie zamknięty ${ }^{65}$. Problemem okazało się również zdobycie ważnych dokumentów, które poświadczyłyby, że strona żydowska posiada gwarantów, takich jak przyjaciele czy krewni na całym świecie, do których mogliby udać się uchodźcy po dotarciu do Japonii66.

Jan Zwartendijk, który czasowo urzędował w Kownie, zdecydował się na spotkanie z japońskim konsulem i pięcioma żydowskimi uchodźcami. Sugihara wyraził wątpliwość, czy w Curaçao istnieją odpowiednie warunki na przyjęcie tak dużej liczby osób. Zapytał więc Zwartendijka, czy na Curaçao jest miejsce, w którym można wylądować; ten odpowiedział, że nie wie, jeszcze tego nie sprawdził67. Zwartendijk otrzymał pozwolenie od swojego przełożonego w Rydze, L.P.J. de Deckera na wystawianie wiz na Curaçao za pobraniem opłaty, jednak wystawienie aż tak wielu wiz niosło również dla niego ogromne niebezpieczeństwo ${ }^{68}$.

Sugihara Chiune mógł samodzielnie wystawić jedynie kilka wiz, na wystawienie większej ich liczby potrzebował zezwolenia japońskiego Ministerstwa Spraw Zagranicznych. Konsul zdecydował się poinformować Ministerstwo o swojej decyzji wydania wiz dla wszystkich uchodźców, jednocześnie prosząc o wyrażenie zgody na takie działanie. Pierwszy bezpośredni kontakt z Ministerstwem Spraw Zagranicznych został nawiązany za pomocą depeszy szyfrowej, którą osobiście kodowała Yukiko69. Jej kopie zostały przesłane m.in. do ambasady Japonii w Niemczech i do ministra spraw zagranicznych w Tokio, Matsuoki Yōsuke. Treść telegramu brzmiała następująco:

„Setki osób żydowskiego pochodzenia przyszły do konsulatu w Kownie w celu otrzymania wiz tranzytowych. Osoby te bardzo cierpią. Jako człowiek nie mogę pozostać obojętnym na ich prośby. Proszę o pozwolenie na wystawienie wiz dla tych ludzi"70.

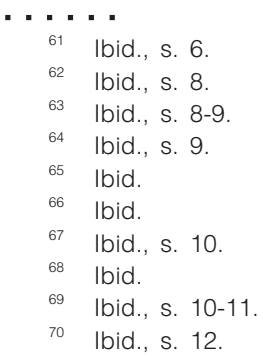


Jednak odpowiedź z Ministerstwa Spraw Zagranicznych była negatywna:

„Dotyczy uprzednio złożonej prośby o pozwolenie na wystawienie wiz tranzytowych. Stop.

Zaleca się absolutnie nie wydawać wizy podróżnemu nieposiadającemu wizy docelowej gwarantującej wyjazd z Japonii. Stop. Bez wyjątków. Stop. Nie oczekujemy na dalsze zapytania. Stop. K. Tanaka, Ministerstwo Spraw Zagranicznych, Tokio"71.

Przez dwa dni po otrzymaniu odpowiedzi Sugihara Chiune zastanawiał się, co zrobić; w tym czasie coraz więcej ludzi pojawiało się przed japońską placówką dyplomatyczną. Sugihara obliczył, że uchodźcom na podróż przez Związek Radziecki potrzebne będzie minimum dwadzieścia dni, a następne trzydzieści na pobyt w Japonii. Dało to sumę pięćdziesięciu dni, jakich potrzebują emigranci, aby dostać się do kraju przeznaczenia od momentu wystawienia wizy ${ }^{72}$. W związku z tym japoński konsul wysłał kolejny telegram, jednak ponownie odmówiono mu zgody na wystawianie wiz.

Przyczyną odmowy ze strony japońskiego MSZ mogło być, według Sugihary Yukiko, stwierdzenie Ministerstwa Spraw Wewnętrznych w Japonii, że przyjęcie tak dużej liczby ludzi może zaszkodzić bezpieczeństwu narodowemu. Również firma zajmująca się przewozem osób drogą morską między Władywostokiem a Tsurugą odmówiła współpracy ${ }^{73}$.

23 sierpnia 1939 roku zawarto pakt o nieagresji pomiędzy Niemcami a Związkiem Radzieckim. Rok później, w sierpniu, dokonana została aneksja Litwy przez państwo radzieckie, czego konsekwencją było m.in. polecenie zamknięcia japońskiego konsulatu w Kownie. W tej sytuacji Chiune postanowił jeszcze raz wysłać telegram do japońskiego Ministerstwa Spraw Zagranicznych. W tym samym czasie podjął decyzję o udzieleniu pomocy oczekującym pod konsulatem Żydom i po porozumieniu się z żoną stwierdził: „(...) Wystawię wizy bez zgody Ministerstwa Spraw Zagranicznych, posługując się prawem, jakie mam jako konsul. (...) Jednak nie wiem, jaki nas los spotka"74. Sugihara zdawał sobie sprawę z tego, że taki czyn spowoduje usunięcie go z Ministerstwa Spraw Zagranicznych, a jego decyzja będzie odebrana jako działanie przeciwko rządowi japońskiemu. Jednak, gdy spojrzał przez okno, powiedział do żony:

„Muszę coś zrobić. Młody człowiek przychodzi do mojego domu po pomoc. Czy jest niebezpieczny? Nie. Czy jest szpiegiem? Nie. Czy jest zdrajcą? Nie. Jest tylko żydowskim nastolatkiem, który chce żyć. Muszę sprzeciwić się swojemu rządowi, bo jeśli tego nie zrobię, sprzeciwię się Bogu"75.

Sugihara Chiune zdecydował się na wystawienie wiz, ryzykując zniszczenie własnej kariery dyplomatycznej, czy nawet swe życie. Następnego dnia udał się do ambasady Związku Radzieckiego i uzyskał zgodę na przejazd żydowskich uchodźców przez terytorium ZSRR. Pomogły mu w tym pobudki ekonomiczne, jakimi kierowały się władze radzieckie, pobierające od żydowskich uchodźców podwójną opłatę za przejazd Koleją Transsyberyjską ${ }^{76}$.

Dzień po spotkaniu w ambasadzie radzieckiej Sugihara Chiune ogłosił zgromadzonym: „Wystawię wizę każdemu z was, proszę cierpliwie czekać”77. Gdy otwarto bramę

lbid., s. 13

Ibid., s. 15-16.

Ibid., s. 16

Ibid., s. 17

Ibid., s. 18-19.

Ibid., s. 19

Ibid., s. 20-21 
przed konsulatem, tłum próbował dostać się do budynku. Bolesław Różycki rozdawał więc numerki, wyznaczające kolejność wchodzenia do gabinetu konsula.

Ponieważ nieoficjalnym celem działalności konsulatu Japonii w Kownie było obserwowanie działań III Rzeszy i Związku Radzieckiego, liczba odpowiednich druków wizowych była zbyt mała, aby wydać je wszystkim oczekującym. Dlatego Sugihara musiał wypisywać wszelkie niezbędne informacje odręcznie ${ }^{78}$. Początkowo konsulat był czynny od godziny dziewiątej rano do piątej po południu, jednak konsul w ostatnich dniach sierpnia pracował od godziny ósmej aż do bardzo późnych godzin wieczornych ${ }^{79}$. Sugihara Yukiko informowała męża o liczbie osób, które nadal czekały przed bramą. On sam potrafił wypisać do trzystu wiz dziennie, jednak zdarzały się dni, w których wydanych dokumentów było mniej z powodu braku tuszu czy papieru. Każda wiza była dokumentem składającym się z dwóch lub trzech pełnych akapitów, toteż brak gotowych wzorów dokumentów powodował wydłużenie czasu wystawienia wizy. Na początku Sugihara numerował wizy i wpisywał je na listę, jednak później zrezygnował z tej procedury, aby zyskać na czasie ${ }^{80}$. Opłaty za wystawianie wiz przekazywane były na konto japońskiego Ministerstwa Spraw Zagranicznych przez Litewski Bank Narodowy (przekształcony 6 sierpnia 1940 roku w oddział Państwowego Banku ZSRR). Taki stan rzeczy trwał około miesiąca, przy jednoczesnych żądaniach ze strony rządu radzieckiego, aby japoński konsul opuścił Kowno ${ }^{81}$. Zignorowane zostało również żądanie japońskiego Ministerstwa Spraw Zagranicznych z 2 sierpnia 1940 roku, aby Sugihara jak najszybciej wyjechał z miasta. Po skierowaniu prośby do radzieckiej ambasady, konsul otrzymał ze strony radzieckiej pozwolenie na pozostanie w Kownie do końca sierpnia 1940 roku².

Sugihara Chiune kontynuował wystawianie wiz do 28 sierpnia 1940 roku³. Władze radzieckie i japońskie Ministerstwo Spraw Zagranicznych wciąż nalegały, aby konsul zamknął placówkę i wyjechał do Berlina. Do rąk Chiune trafił telegram z Ministerstwa, w którym napisano, iż Litwa znajduje się pod okupacją radziecką i nie jest już niepodległym krajem ${ }^{84}$. W związku z tą sytuacją Sugihara musiał ostatecznie zamknąć konsulat i przygotować się do wyjazdu do Niemiec. Przed wyjazdem spalił wszelkie dokumenty, aby nie dostały się w ręce Rosjan ${ }^{85}$.

Do momentu opuszczenia Kowna Sugihara kontynuował wypisywanie wiz, m.in. w hotelu Metropolis, gdzie zatrzymał się wraz z rodziną. W chwili odjazdu, znajdując się już w pociągu, Chiune zwrócił się do stojących na peronie Żydów: „Wybaczcie mi. Nie mogę już dłużej. Życzę wam wszystkiego dobrego"86.

\section{SYTUACJA ŻYDÓW POLSKIEGO POCHODZENIA}

Gdy we wrześniu 1939 roku Niemcy i Związek Radziecki napadły na Polskę, wielu Żydów polskiego pochodzenia zaczęło szukać najlepszej drogi ucieczki z okupowanego kraju, w którym stopniowo wprowadzano represje wobec osób wyznania mojżeszo-

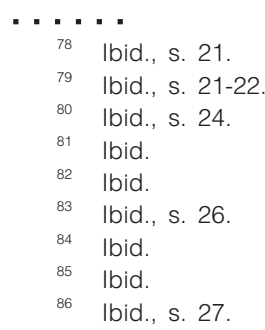


wego. Wśród nich byli bohaterowie filmu Wizy życia - czyli japoński szlak z litewskiej pułapki w reżyserii Andrzeja Miłosza i Piotra Weycherta. Nathan Szlosberg opuścił Warszawę 7 września, kierując się w stronę wschodnich granic Rzeczypospolitej. Zorach Warhaftig udał się w tamtym kierunku, gdy we wrześniu 1939 roku rząd w Moskwie przekazał Litwie Wilno i Wileńszczyznę. Mordechaj Tsanin, wierząc, że Armia Czerwona przyjmie uchodźców, również wyruszył na wschód, jednak w Białymstoku stracił nadzieję, gdy zorientował się, że żydowscy komuniści urządzają łapanki na starozakonnych.

W tym czasie w Wilnie, w siedzibie ojców jezuitów, z inicjatywy księdza Kazimierza Kucharskiego powstała organizacja pomocy uchodźcom, która oprócz akcji charytatywnych zajmowała się również konspiracją. Jak wspomina Wanda Kiałka, ksiądz Kucharski zorganizował komórkę wydającą dokumenty dla powracających z frontu żołnierzy. Pomagał mu w tym współpracujący z organizacją od października 1939 roku ksiądz Stefan Dzierżek, a także Janina Kruk-Szczerba, która podrabiała dokumenty dla osób potrzebujących tego rodzaju pomocy. Wanda Kiałka w wywiadzie powiedziała również, że „fałszywe dokumenty dostarczał były starosta wileński i parafie kościołów"87.

Początkowy status pozornie niezależnej Litwy budził poczucie bezpieczeństwa w przybywających na te tereny uchodźcach. Na początku 1940 roku przebywało w Wilnie około 20000 osób pochodzenia żydowskiego. Ludzi tych wspomina Irena Jaruszyńska:

\begin{abstract}
„Jeżeli chodzi o charakterystykę uchodźców, to były to grupy różnorodne, ale wszyscy aktywni bardzo. Albo byli to działacze polityczni wszystkich kierunków, którzy czuli się zagrożeni ze strony Niemiec, a drugiej strony już po doświadczeniach pierwszych pobytów Sowietów. W Wilnie zebrało się w gruncie rzeczy właściwie kierownictwo wszystkich żydowskich ugrupowań istniejących na terenie Polski" ${ }^{\prime 8}$.
\end{abstract}

W tym czasie wielu uchodźców, w tym Izaak Lapon, „szukało możliwości, jak wydostać się z Wilna na wolny świat" ${ }^{2}$. Zorach Warhaftig, ówczesny przewodniczący Komitetu Ocalenia Polskiego Żydostwa ${ }^{90}$, starał się zdobyć dla uchodźców wizy wjazdowe do Palestyny i innych państw, jednak z uzyskaniem tych pierwszych był problem, gdyż jak twierdzi Irena Jaruszyńska: „Do Palestyny wiz Anglicy nie dawali ze względu na stosunki z Arabami, których nie chcieli drażnić"91. Uchodźcy chodzili od konsulatu do konsulatu. Mordechaj Tsanin wspomina, że żadne państwo nie chciało ratować żydowskich uchodźców, Anglicy zamykali granice, organizacje żydowskie ratowały tylko swoich członków, Żydzi amerykańscy pozostawali obojętni na problem zaistniały w Europie.

Późną wiosną 1940 roku konsul Sugihara wraz z oficerami polskiego wywiadu Michałem Rybikowskim, Alfonsem Jakubiańcem i Leszkiem Daszkiewiczem ustalili szlak przerzutowy dla polskich oficerów. Wiódł on z Wilna przez Moskwę, Koleją Transsyberyjską do Władywostoku, tranzytem przez Japonię do Curaçao, ale faktycznym miejscem przeznaczenia miała być Wielka Brytania. Generał Yamawaki, attaché obrony w Warszawie w latach 1921-22 i 1934-35, odznaczony w 1920 roku przez marszałka Józefa Piłsudskiego orderem Virtuti Militari (jako obserwator bitwy pod Radzyminem), obiecał sześćset japońskich wiz tranzytowych dla polskich oficerów92. Jednak gdy wschodnie terytorium Rzeczypospolitej, na którym znajdowali się oficerowie, dostało się pod kontrolę ZSRR,

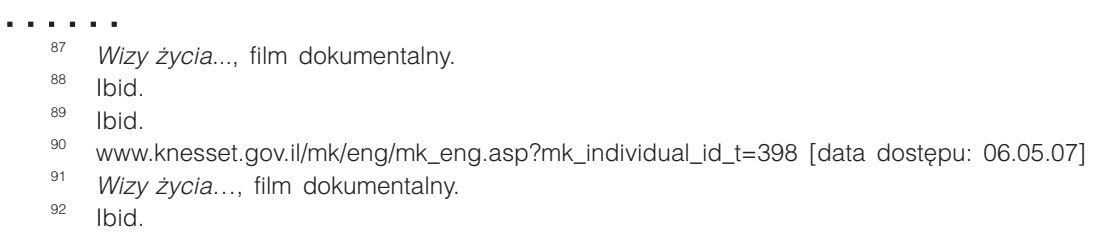


polscy żołnierze zostali deportowani na wschód lub zamknięci w radzieckich obozach internowania ${ }^{93}$.

Gdy 15 czerwca 1940 roku do Wilna wkroczyła Armia Czerwona, wielu uchodźców znalazło się na terytorium między dwoma wrogimi narodami. Władze radzieckie rozpoczęły aresztowania przedstawicieli organizacji syjonistycznych i wywóz ich na Syberię. W tym czasie znajdujący się w Wilnie Żydzi dowiedzieli się, że holenderski konsul wydaje wizy do Curaçao, a następnie, że jeśli dostaną zaświadczenie, iż wiza wjazdowa na tamte tereny jest zbędna, pełniący służbę w Kownie japoński konsul Sugihara wyda dla nich wizy tranzytowe przez Japonię. Nathan Szlosberg wspomina; „Wielu ludzi uważało nas (...) za bardzo lekkomyślnych, bo wiza do Curaçao była fikcją"94. Gdy żydowscy uciekinierzy pojawili się przed konsulatem, był wśród nich Aszer Gorfajn, który relacjonuje, że o godzinie trzeciej wyszedł z konsulatu pewien Polak, zaprosił kilka osób na kawę i zapytał, w jakim celu tu przybyli. O godzinie siedemnastej przyjechał konsul Sugihara i zaprosił między innymi Gorfajna do swojego pokoju, gdzie rozmawiali o tym, skąd uchodźcy wezmą pieniądze na przejazd do Japonii. Przybyli Żydzi odpowiedzieli wymijająco, że nie mają innego wyjścia, więc muszą spróbować. Również Mordechaj Tsanin bardzo dobrze wspomina spotkanie z konsulem Sugiharą, w czasie którego, po krótkiej rozmowie, konsul wystawił dla niego wizę. Młody żydowski chłopak zapamiętał twarz konsula, która wydawała mu się niezwykle ludzką, o szczególnym wyglądzie ${ }^{95}$.

Ksiądz Stefan Dzierżek wspomina, że w czasie, gdy zamykano japoński konsulat w Kownie, organizacja podziemna posiadała jako „wtyczkę” byłego polskiego oficera, który pracował w kowieńskiej pieczątkarni. Człowiek ten zrobił kopię pieczątki, którą Sugihara wcześniej u niego zamówił. Wersję tę potwierdza por. Daszkiewicz w opublikowanym po wojnie sprawozdaniu ze swej działalności:

„(...) pewnego dnia konsul Sugihara powiedział mnie, że ma duże trudności przy wpisywaniu ustalonej formuły na paszportach w języku japońskim i to hamuje w dużym stopniu szybkie załatwianie interesantów. Zaproponowałem jemu, czy nie dałoby się zrobić pieczęci gumowej, a on wpisywałby tylko pozostałość i podpis. Zgodził się na mój projekt i dał mi wzór. Wzór ten oddałem kpt. Jakubiańcowi, który zamówił pieczęć, lecz kazaliśmy zrobić w dwóch egzemplarzach i jeden został przekazany do Wilna, gdzie wystawiano potem wizy tranzytowe japońskie, lecz robione po wyjeździe konsula japońskiego z Kowna, z datą wcześniejszą" ${ }^{\prime \prime 6}$.

W tym samym czasie japoński konsul wyposażył Jakubiańca i Daszkiewicza w bezpieczne paszporty i wysłał ich do Berlina.

\section{LOS ŻYDÓW PO WYJEŹDZIE KONSULA Z KOWNA}

Według wspomnień księdza Stefana Dzierżka, z Komendy Okręgu Wileńskiego wyszło polecenie wydawania polskich paszportów z wizą japońską dla Żydów. Dokumenty te znalazły się w posiadaniu podziemia po likwidacji polskich urzędów w Wilnie. Wydawanie takich dokumentów z japońskimi wizami było możliwe dzięki temu, że radzieccy kontrolerzy nie znali języka japońskiego. Mąż Wandy Kiałki uczył się przepisywać znaki japońskie i wypisywał fałszywe wizy. Wielu Żydów, wśród nich Menachem Schubert, dowiedziawszy się o możliwości otrzymania takich dokumentów, kupowało wizy do Japonii.

$\because$.. -

93 N. Davies, Boże igrzysko. Historia Polski, Wydawnictwo Znak, Kraków 2006, s. 910-911, 914.

94 Wizy życia..., film dokumentalny.

95 Ibid

96 E. Pałasz-Rutkowska, A.T. Romer, Historia stosunków..., s. 185. 
Jedna z wystawiających fałszywe dokumenty osób, Bat-Szewa Hutner, opowiada:

„Przychodzili do mnie ludzie z pustymi dokumentami, a ja własnoręcznie wszystko wypełniałam i podpisywałam w miejscach przeznaczonych dla urzędników. Dostawałam blankiety ze stemplami, ale niewypełnionymi informacjami (...). Uzupełniałam dane osobiste w miejscach do tego przeznaczonych" ${ }^{\prime 97}$.

Aby opuścić terytorium Litwy, potrzebna była wiza wyjazdowa. W celu otrzymania stosownego dokumentu należało zgłosić się do siedziby NKWD. Ponieważ udanie się po takie dokumenty było bardzo niebezpieczne, ze względu na możliwość aresztowania, komisarz ds. uchodźców, który był Polakiem, wydawał na krótki czas teczki osób zainteresowanych, a treść akt w nich zawartych zamieniana była przez Mordechaja Tsanina ${ }^{98}$. W ten sposób osoby, które pełniły znaczące funkcje przed wybuchem wojny, otrzymywały życiorys zwykłego robotnika.

Żydzi posiadający japońską wizę tranzytową przewożeni byli przez 12 dni w specjalnych wagonach Kolei Transsyberyjskiej, a ich paszporty znajdowały się w rękach eskortujących ich pracowników NKWD. Po przyjeździe do Władywostoku grupa przybyłych uchodźców kierowana była na statek japoński. Jednak przed odpłynięciem statku zdarzały się takie przypadki, o jakich wspomina Bat-Szewa Hutner: „Zabrali mnie na śledztwo NKWD, przed odpłynięciem. Pytali, czy to ja fałszowałam dokumenty. Oczywiście zaprzeczyłam wszystkiemu"99.

Jak mówi jedna z uciekających, Perla Frankel, na statku, który wyruszał z Władywostoku było około trzystu osób. Mordechaj Tsanin wspomina, że podczas podróży do Japonii byli eskortowani przez płynący za nim statek radziecki.

Gdy w japońskim porcie podczas kontroli okazało się, że osiemdziesiąt osób posiada sfałszowane dokumenty, zostali oni odesłani z powrotem do Władywostoku. Polski ambasador w Tokio Tadeusz Romer został wezwany przez japońskie Ministerstwo Spraw Zagranicznych w celu wręczenia noty, że na terytorium Japonii chciało przedostać się trzydziestu Jakubów Goldbergów ${ }^{100}$. Jednak ambasador RP zdobył zezwolenia na przyjęcie tych osób na maksymalnie trzy tygodnie.

W październiku 1940 roku Romer wraz z żoną zorganizował Polski Komitet Pomocy Ofiarom Wojny, który nawiązał kontakt z organizacjami żydowskimi w Jokohamie i Kobe. Komitet ten udzielał pomocy zarówno w dostarczaniu rzeczy codziennego użytku, jak i w staraniach o wydanie wiz tych państw, które mogły okazać się docelowymi dla uchodźców z Kowna ${ }^{101}$. Po przyjeździe do Japonii uchodźcy kierowani byli przez tę organizację do Kobe, jak również otrzymywali pomoc w załatwianiu wszelkich formalności konsularnych. Żydowska gmina w Kobe zajmowała się kwestią mieszkaniową, otrzymując na ten cel stosowne fundusze z Committees for Assistance to Jewish Immigrants from Eastern Europe ${ }^{102}$. Łącznie ze wszystkich źródeł wydano na polskich uchodźców sumę około 350000 dolarów amerykańskich w okresie do 1 lipca 1942 roku103.

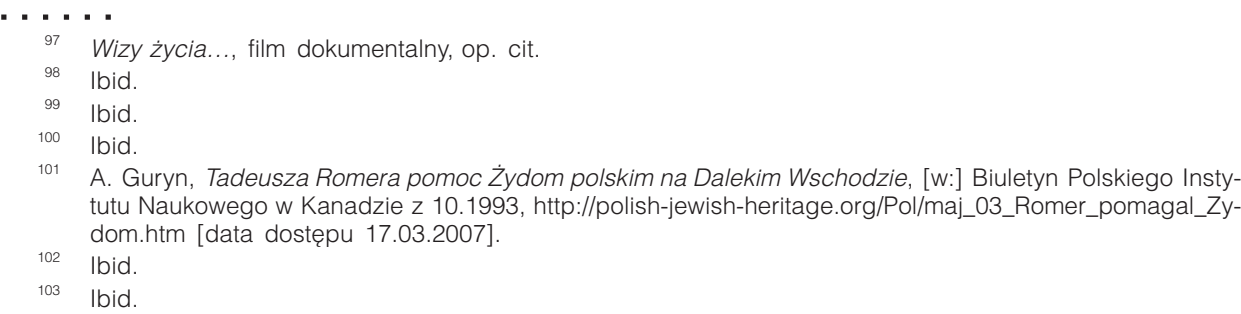

101 A. Guryn, Tadeusza Romera pomoc Żydom polskim na Dalekim Wschodzie, [w:] Biuletyn Polskiego Instytutu Naukowego w Kanadzie z 10.1993, http://polish-jewish-heritage.org/Pol/maj_03_Romer_pomagal_Zydom.htm [data dostępu 17.03.2007]. 
Ambasador Romer zapewnił Żydom polskiego pochodzenia następującą liczbę wiz azylowych: 250 do Kanady, 65 do Australii, 30 do Nowej Zelandii i 50 do Birmy. Również dzięki działaniom ambasady uzyskano 400 certyfikatów wjazdowych do Palestyny, wizy dla około 300 osób do Stanów Zjednoczonych oraz około 100 wiz do krajów Ameryki Środkowej i Południowej ${ }^{104}$.

Gdy w październiku 1941 roku nastąpiła likwidacja ambasady polskiej w Tokio, pozostali do tej pory w Japonii żydowscy uchodźcy otrzymali pozwolenie na zasiedlenie będącego pod kontrolą japońską wyznaczonego sektora w Szanghaju ${ }^{105}$.

\section{OPINIE O CZYNIE SUGIHARY}

\section{POBUDKI MATERIALNE}

Po zakończeniu II wojny światowej w opinii publicznej pojawiły się różnego rodzaju spekulacje na temat pobudek materialnych, jakimi mógł się kierować konsul Sugihara Chiune w trakcie wystawiania wiz tranzytowych przez Japonię. Ponieważ część materiałów jest nadal utajniona (zwłaszcza materiały radzieckie), a niektóre fakty - niejasne, pojawiają się różne dywagacje na ten temat. $Z$ tego względu wszystkie przypuszczenia należy traktować w sposób niezwykle ostrożny. Najostrzejszą, a zarazem najbardziej kontrowersyjną ocenę moralną zachowania konsula przedstawił Basilius Besler w artykule zatytułowanym Sugihara Story: Facts, Mystery, Myth ${ }^{106}$.

Według niego najbardziej oczywistym powodem, dla którego japoński konsul mógł przyjąć od Żydów pewną kwotę pieniędzy, było zdobycie radzieckich wiz tranzytowych, bez których podróż do Japonii i na Curaçao byłaby niemożliwa. Besler zastanawia się, czy ZSRR, biorący udział w wojnie i jednocześnie zagrożony (mimo zawarcia paktu o neutralności) japońskim atakiem, mógł się zgodzić na przejazd tysięcy obcokrajowców - Żydów przez swoje terytorium, nie odnosząc z tego jakichkolwiek korzyści, poza finansowymi. Jedyną bowiem szansą na wydanie wiz przez ZSRR było zapłacenie za transfer uciekających osób Koleją Transsyberyjską i ich pobyt w Moskwie. Warto zaznaczyć, że na jedną wizę często podróżowało kilka osób, co według autora przyniosło znaczny dochód z tego rodzaju pomocy.

Założona w 1914 roku w Stanach Zjednoczonych organizacja wspierająca finansowo Żydów mieszkających poza terytorium amerykańskim (Joint Distribution Committee), również niosła pomoc osobom uciekającym na wschód po otrzymaniu wiz tranzytowych przez Japonię ${ }^{107}$. Jeden z polskich pracowników Jointu otrzymał zezwolenie od rządu Związku Radzieckiego na podróżowanie przez Syberię w celu towarzyszenia przewożonym Żydom przybyłym z Kowna. Był nim Joseph Shimkin, wspomniany również w artykule Ihary Keiko Swindler's List. Joseph Shimkin's Humanitarian Fraud ${ }^{108}$. Shimkin

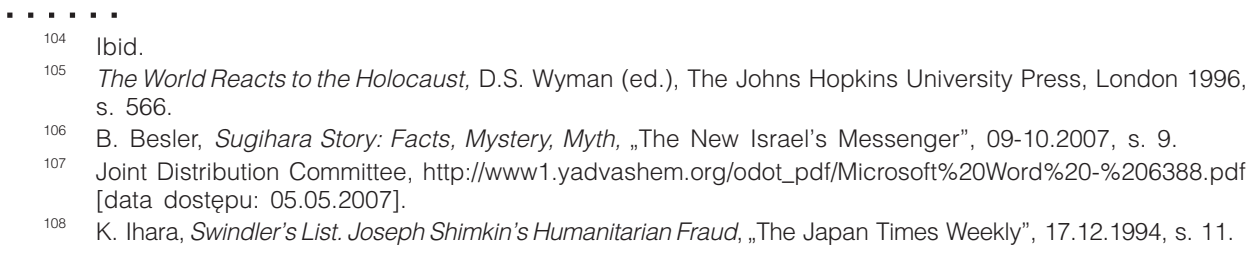

105 The World Reacts to the Holocaust, D.S. Wyman (ed.), The Johns Hopkins University Press, London 1996, S. 566.

106 B. Besler, Sugihara Story: Facts, Mystery, Myth, „The New Israel's Messenger”, 09-10.2007, s. 9.

107 Joint Distribution Committee, http://www1.yadvashem.org/odot_pdf/Microsoft\%20Word\%20-\%206388.pdf [data dostępu: 05.05.2007].

108 K. Ihara, Swindler's List. Joseph Shimkin's Humanitarian Fraud, „The Japan Times Weekly”, 17.12.1994, s. 11. 
wspominany jest jako główny organizator wsparcia logistycznego dla Żydów posiadających wizę tranzytową do Japonii, jak również jako osoba, która towarzyszyła wielu spośród nich w podróży do Władywostoku. Besler przypuszcza, że Shimkin kooperował z radzieckim wywiadem. Posiadana przez niego wiza amerykańska została mu anulowana podczas jego pobytu w Japonii, co uniemożliwiło mu powrót do Stanów Zjednoczonych, zmuszając go do pozostania w Japonii i - według Beslera - prowadzenia akcji wywiadowczej na rzecz Związku Radzieckiego ${ }^{109}$.

Tezom Beslera przeczy przedstawiony przez Keiko Iharę fakt, że Amerykanie cofnęli Shimkinowi wizę, podejrzewając go raczej o kontakty z III Rzeszą niż Związkiem Radzieckim ${ }^{110}$. Postawa Josepha Shimkina została jednak doceniona przez Sugiharę Chiune, z którym spotkał się on w izraelskiej ambasadzie w Tokio.

Watanabe Katsumasa, autor książki Shinzō. Sugihara biza (Prawda. Wizy Sugihary), polemizuje z krytycznymi opiniami na temat bezinteresowności konsula, udowadniając, że twierdzenie o pobudkach materialnych Sugihary przy wystawianiu wiz dla Żydów jest plotką, prawdopodobnie wymyśloną przez japońskie Ministerstwo Spraw Zagranicznych ${ }^{111}$. Autor uważa, że resort dyplomacji nie posiadał żadnych dowodów na to, że pobrana została jakakolwiek inna opłata za wystawienie dokumentów poza urzędową, która wpłynęła na konto Ministerstwa Spraw Zagranicznych Japonii. Jednocześnie stwierdza, że plotka ta była sprowokowana działalnością Żydów amerykańskich, którzy chcieli wpłynąć na dwa japońskie rządy - Shidehary i Yoshidy - aby nominować Sugihare na ambasadora w Stanach Zjednoczonych ${ }^{112}$. Próby zewnętrznej ingerencji budziły niezadowolenie w japońskim rządzie i mogły być jednym z czynników, które wpłynęły na zwolnienie Sugihary z Ministerstwa Spraw Zagranicznych ${ }^{113}$. Tezę tę można poprzeć stwierdzeniem, że Sugihara nie dostał żadnego upomnienia za swoją kowieńską działalność, aż do roku 1947114. Po opuszczeniu Kowna Sugihara został bowiem skierowany do Pragi - skąd ostatecznie przesłał do MSZ sprawozdanie na temat działalności w Kownie - a następnie oddelegowany na kolejne placówki: w Królewcu i Bukareszcie. Opieszałość japońskich zwierzchników służby zagranicznej można jednak wytłumaczyć także trwającą wojną, która ograniczała ich aktywność.

IZRAEL

Przez dwadzieścia osiem lat od wydarzeń z Kowna żaden z Żydów, którzy otrzymali wizy od Sugihary, nie nawiązał z nim kontaktu. Tłumaczono to niemożnością odnalezienia Sugihary Chiune z powodu dwóch wersji odczytu znaków, którymi zapisane było imię konsula. Otóż można je odczytać jako Chiune (czytanie japońskie) oraz jako Sempo (czytanie sino-japońskie), przy czym właśnie to drugie czytanie było znane Żydom, którzy dzięki wizom ocaleli z Holocaustu115. To właśnie spowodowało, że dopiero w 1968 roku Żydzi odnaleźli Sugiharę, pracującego wówczas w Moskwie, lecz chwilowo przebywającego na urlopie w Japonii. Poproszono go telefonicznie o przybycie do

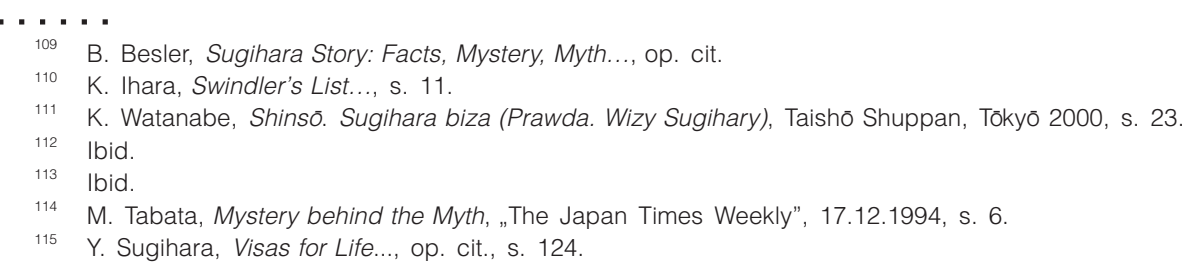


ambasady Izraela. Attaché gospodarczy Izraela w Tokio Nishiri był bowiem jedną z pięciu osób, które w lipcu 1940 roku przedstawiły Sugiharze swoją prośbę o wystawienie wiz tranzytowych ${ }^{116}$. W chwili wyjazdu konsula z Kowna obiecał mu, że spotkają się jeszcze raz. W 1968 roku postanowił wypełnić daną obietnicę. Przy okazji spotkania zaproponowano Sugiharze, aby w dowód wdzięczności jego najmłodszy syn przyjął stypendium Uniwersytetu Hebrajskiego ${ }^{117}$.

Wiadomość o tym zdarzeniu została zamieszczona w „Asahi Shimbun” 2 sierpnia 1968 roku, będąc jednocześnie pierwszą medialną wzmianką na temat czynu Sugihary w czasie II wojny światowej18. Po dwóch miesiącach od tej wizyty Sugihara Chiune po raz pierwszy udał się z wizytą do Izraela, gdzie spotkał się z Zorachem Warhaftigiem, ocalałym Żydem z Kowna, który wówczas pełnił funkcję ministra do spraw religii w izraelskim rządzie, jak również był jedną z osób, które podpisały Deklarację Niepodległości Izraela ${ }^{119}$. Sugihara gościł również u wiceburmistrz Tel Awiwu, Sofii Krementenowski ${ }^{120}$.

Zasługi Sugihary najpełniej doceniono w 1984 roku, gdy został on nagrodzony przez Yad Vashem tytułem Sprawiedliwego wśród Narodów Świata ${ }^{121}$. Oficjalna uroczystość miała miejsce w ambasadzie Izraela w Tokio 18 stycznia 1985 roku, jednak z powodu złego stanu zdrowia konsul nie mógł w niej uczestniczyć. Reprezentowali go żona Yukiko i syn Hiroki. Ceremonia była relacjonowana przez światowe media. Kilkanaście dni wcześniej Sugihara został zaproszony do Centrum Społeczności Żydowskiej w Tokio, gdzie uczestniczył w oficjalnym powitaniu ministra spraw zagranicznych Izraela Icchaka Szamira. Propozycja przyjazdu Szamira do Japonii została wysunięta przez premiera Nakasone Yasuhiro, w celu pogłębienia przyjaznych stosunków między obydwoma krajami.

Gdy 30 lipca 1986 roku ambasador Izraela Yaacov Cohen dowiedział się o śmierci Sugihary, przyszedł do domu zmarłego konsula, aby oddać mu hołd.

\section{LITWA}

Po II wojnie światowej terytorium Litwy znalazło się pod okupacją Związku Radzieckiego. W tym czasie temat Holocaustu nie był poruszany. Dopiero gdy w 1990 roku Litwa ogłosiła niepodległość, również sprawa Sugihary Chiune doczekała się zainteresowania ze strony tego państwa.

W 1999 roku swoją działalność rozpoczęła Fundacja Sugihary - Dyplomaci Życia. Jej celem jest kultywowanie pamięci o japońskim konsulu, jak również o innych dyplomatach, którzy podczas wojny pomagali potrzebującym ${ }^{122}$. Fundacja zbiera również fundusze na badania dotyczące ofiar Holocaustu i promuje współpracę kulturalną między Litwą a Japonią. Współpracę z Fundacją Sugihary podjął Uniwersytet Vytautas Magnus, gdzie otworzone zostało Centrum Studiów Japońskich.

Także dzięki staraniom Litwinów, przy Vaižganto gatvè 30 w Kownie, gdzie w 1940 roku mieścił się japoński konsulat, otworzono muzeum Sugiharos namai (Dom Sugihary). Było to możliwe po odkupieniu budynku od skarbu państwa w 1992 roku przez syna

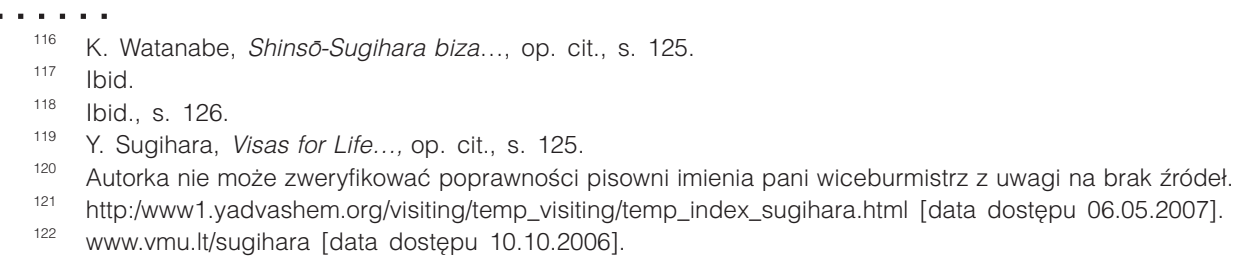


poprzedniego właściciela, Rimantasa Juozapasa Tonkūnasa ${ }^{123}$. Ponadto dla uczczenia pamięci Sugihary Chiune jednej z wileńskich ulic nadano jego imię.

Dla obu państw postać Sugihary Chiune jest zatem symboliczna. Aby to podkreślić, w 2000 roku połączono uroczystości związane z setną rocznicą urodzin Sugihary z dziewięcioleciem odnowienia stosunków dyplomatycznych ${ }^{124}$.

PODSUMOWANIE

Wydarzenia, które miały miejsce w Kownie w 1940 roku - mimo ich humanitarnego wydźwięku - negatywnie wpłynęły na dalszą karierę dyplomatyczną Sugihary Chiune. Gdy po dziesięciu latach pobytu za granicą konsul wraz z rodziną powrócił do Japonii, został zwolniony z Ministerstwa Spraw Zagranicznych. Miało to miejsce w 1947 roku $^{125}$.

Wspomniany wyżej autor wielu publikacji na temat Sugihary, Watanabe Katsumasa, przedstawił argumenty, które jego zdaniem wpłynęły na decyzję o zwolnieniu byłego konsula z resortu dyplomacji. Gdy Japonia skapitulowała po klęsce w II wojnie światowej, wszyscy dyplomaci zostali wycofani ze swoich placówek. Ministerstwo Spraw Zagranicznych rozpoczęło weryfikację swoich pracowników. Jedna trzecia dyplomatów została zwolniona. Działalność Sugihary na Litwie została oceniona negatywnie, ze względu na niewykonanie poleceń Ministerstwa Spraw Zagranicznych ${ }^{126}$. Krótko po zakończeniu działań wojennych stosunki zewnętrzne Japonii - z uwagi na amerykańską okupację - uległy drastycznemu ograniczeniu aż do 1952 roku, zaś liczbę dyplomatów zredukowano. Aby ochronić wyjątkowo zdolnych pracowników dyplomatycznych, premier Shidehara Kijūrō i minister spraw zagranicznych Yoshida Shigeru otworzyli specjalny ośrodek szkoleniowy dla dyplomatów. Osoby, które mogły do niego wstąpić, były starannie selekcjonowane, a chroniący system biurokratyczny Shidehara, nie mógł pozostawić osoby takiej jak Sugihara w Ministerstwie Spraw Zagranicznych ze względu na niesubordynację ${ }^{127}$.

Kolejnym argumentem Watanabe był fakt, że władze japońskie brały pod uwagę wykształcenie swych pracowników. Sugihara przerwał naukę na Uniwersytecie Wasedy i wyjechał do Mandżurii na stypendium MSZ. Mimo że Sugihara wielokrotnie prosił o zezwolenie na powrót do kraju w celu przystąpienia do egzaminów na studia wyższe w kraju, nie otrzymał zgody ${ }^{128}$. W związku z tym po wojnie był pracownikiem nieposiadającym odpowiedniego wykształcenia, co spowodowało, że stał się bezużyteczny ${ }^{129}$. Wpływ na zwolnienie miał również wiek Sugihary, który po powrocie do Japonii skończył czterdzieści siedem lat.

W 1991 roku Ministerstwo Spraw Zagranicznych ponownie zabrało głos w sprawie Sugihary i dopiero wtedy został on zrehabilitowany. 12 sierpnia 1992 roku w Yaotsu odsłonięto pomnik w kształcie organów, upamiętniający działalność konsula na Litwie ${ }^{130}$. . . .

123 http://www.geocities.jp/lithuaniasugiharahouse/indexl.htm

124 http://www.mofa.go.jp/announce/event/2000/10/1003.html [data dostępu 06.05.2007].

125 Y. Sugihara, Rokusenjin-no inochi-no biza (Wizy życia dla 6000 osób), Taishō Shuppan, Tōkyō 1993, s. 219.

126 K. Watanabe, Shinsō. Sugihara biza, s. 20.

127 Ibid., S. 21

128 Ibid

129 Ibid

130 Y. Sugihara, Visas for Life, op. cit., s. 144. 
W uroczystości wzięli udział między innymi Takeshita Noboru, były premier Japonii Kajiwara Taku, gubernator prefektury Gifu Arai Masayoshi, burmistrz Yaotsu i Zorach Warhaftig z Izraela ${ }^{131}$. W tym samym mieście powstał w 1994 roku Park Humanitaryzmu, a w 2000 roku otwarto tu Muzeum Pamięci Sugihary ${ }^{132}$. W tym samym roku, z okazji 100. rocznicy urodzin Sugihary, MSZ odsłoniło w swym Archiwum Dyplomatycznym tablicę pamiątkową.

Najstarszy syn Chiune, Sugihara Hiroki, założył fundację „Wizy Życia”, aby uczcić pamięć swojego ojca. Organizacja ta zajmuje się kultywowaniem pamięci o Sugiharze Chiune i jego czynach dla ludzkościi33.

Pamięć o Sugiharze jest pielęgnowana także przez Fundację Japońską. W 2001 roku stworzyła ona program stypendialny im. Chiune Sugihary, którego celem jest utrzymywanie przyjaznych stosunków między Japonią a Izraelem. Głównym jego założeniem jest wymiana kulturalna między tymi dwoma krajami ${ }^{134}$.

Podziw dla działań Sugihary podczas II wojny światowej wyrażany jest na całym świecie w różnych kręgach społecznych i na wiele sposobów. Jego historii poświęcono wiele filmów fabularnych i dokumentalnych, m.in. Visas and Virtue Chrisa Tashimy, który zdobył w 1997 roku Oscara w kategorii najlepszy film krótkometrażowy. Imię japońskiego konsula otrzymała odkryta w listopadzie 2000 roku asteroida numer $25893^{135}$. Działania Sugihary zostały również docenione przez zespół Savatage, grający metal progresywny. Zespół ten zadedykował japońskiemu konsulowi swój utwór „Chance”, ukazując w nim konflikt myśli, z jakim musiał się uporać Sugihara ${ }^{136}$.

Wobec kontrowersji, jakie wzbudza postać Sugihary Chiune, warto przytoczyć słowa Jolanty Tubielewicz, która w posłowiu do Historii stosunków polsko-japońskich stwierdza:

„W cieniu wielkiej polityki, w zgiełku kilku wielkich wojen i konfliktów zbrojnych, kiedy życie setek tysięcy ludzi stawało się igraszką rozpętanych żywiołów, było jednak miejsce na kultywowanie humanitarnych wartości, na bezinteresowną szlachetność. Najlepszym tego przykładem może być działalność Sugihary Chiune"137.

\section{BIBLIOGRAFIA}

Besler Basilius, Sugihara Story: Facts, Mystery, Myth, „The New Israel's Messenger” nr 06-07.1997, s. 12-14; nr 09-10.1997, s. 8-11

Davies Norman, Boże igrzysko. Historia Polski, Wydawnictwo Znak, Kraków 2006

Fujiwara Nobuo, Chiune Sugihara 1900-1986: A Hero for the 21'st Century, Japan - Israel Chamber of Commerce, 10.2000

Guryn Andrzej, Tadeusza Romera pomoc Żydom polskim na Dalekim Wschodzie, [w:] Biuletyn Polskiego Instytutu Naukowego w Kanadzie z 10.1993, także: http://polish-jewish-heritage.org/Pol/maj_03_Romer_pomagal_Zydom.htm [data dostępu 17.03.2007]

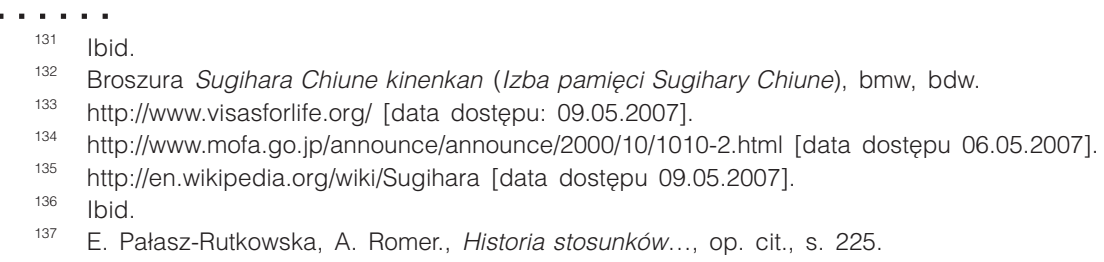

${ }^{137}$ E. Pałasz-Rutkowska, A. Romer., Historia stosunków..., op. cit., s. 225. 
Ihara Keiko, Swindler's List. Joseph Shimkin Humanitarian Fraud, „The Japan Times Weekly" z 17.12.1994

Kopaliński Władysław, Słownik wyrazów obcych i zwrotów obcojęzycznych, wyd. XVII, Państwowe Wydawnictwo Wiedza Powszechna, Warszawa 1967

Krebs Gerhard, The „Jewish Problem” in Japanese-German Relations, 1933-1945, [w:] Japan in the Fascist Era, ed. E. Bruce Reynolds, Palgrave MacMillan, New York 2004

Levine Hiller, Kim pan jest panie Sugihara, Krajowa Agencja Wydawnicza, Warszawa 2000

Pałasz-Rutkowska Ewa, Polityka Japonii wobec Polski 1918-1941, Wydawnictwo Nozomi, Warszawa 1998

Pałasz-Rutkowska Ewa, Romer Andrzej T., Historia stosunków polsko-japońskich 1904-1945, Wydawnictwo Bellona, Warszawa 1996

Pałasz-Rutkowska Ewa, Romer Andrzej T., Polish-Japanese Secret Co-operation during Word War II: Sugihara Chiune and Polish Intelligence, „Japan Forum. The International Journal of Japanese Studies", t. 7 nr 2/1995, Oxford University Press, Oxford, s. 285-317

Sugihara Yukiko, Rokusennin-no inochi-no biza (Wizy życia dla 6000 osób), Taishō Shuppan, Tōkyō 1993

Sugihara Yukiko, Visas for Life, Taishō Shuppan, Tōkyō 1993

Tabata Masanori, Mystery behind the Myth, "The Japan Times Weekly” z 17.12.1994

The World Reacts to the Holocaust, ed. David S. Wyman, The Johns Hopkins University Press, London 1996

The Chiune Sugihara Memorial Hall, broszura informacyjna, Yaotsu, bdw.

Watanabe Katsumasa, Shinsō. Sugihara biza (Prawda. Wizy Sugihary), Taishō Shuppan, Tōkyō 2000

Wizy życia - czyli japoński szlak z litewskiej pułapki, film dokumentalny, reż. Andrzej Miłosz i Piotr Weychert, Grupa Filmowa Kontakt, Agencja Produkcji Teatralnej i Filmowej TVP, 1997

Strony internetowe:

http://en.wikipedia.org/wiki/Shanghai\#19th_to_early_20th_century [data dostępu 08.01. 2007]

www.geocities.jp/lithuaniasugiharahouse/ [data dostępu 05.09.2006]

www.knesset.gov.il/mk/eng/mk_eng.asp?mk_individual_id_t=398 [data dostępu 06.05.07] www.town.yaotsu.gifu.jp/spot/sugihara.sugihara.html [data dostępu 05.09.2006]

Fundacja „Wizy Życia”, http://www.visasforlife.org/ [data dostępu 09.05.2007]

Joint Distribution Committee, www1.yadvashem.org/odot_pdf/Microsoft\%20Word\%20\% 206388.pdf [data dostępu 05.05.2007]

Ministerstwo Spraw Zagranicznych, Tokio, www.mofa.go.jp/ [data dostępu 06.05.2007]

Sugihara Chiune, http://en.wikipedia.org/wiki/Sugihara [data dostępu 16.02.2007]

Sugihara Foundation - Diplomats For Life, www.vmu.It/sugihara [data dostępu 10.10.2006]

Yad Vashem, www1.yadvashem.org/visiting/temp_visiting/temp_index_sugihara.html [data dostępu 06.05.2007] 
CONSUL SUGIHARA CHIUNE AND THE POLISH JEWS IN KAUNAS, LITHUANIA IN 1939-1940

\section{Summary}

The main subject of this article is the life and career of Sugihara Chiune, viewed in the context of the fate of European Jews during their stay in the Lithuanian capital, Kaunas, while they were escaping from Nazi-occupied Europe in 1939 and 1940. The author investigates how the Japanese consul helped them obtain visas and thus saved their lives. She also deals with his private and professional life, including the turns of his diplomatic career in pre-war Lithuania, and his views on crucial issues involving his activities connected with saving the Polish Jews - even at the risk of his own life and the life of his family. Sugihara continued to hand out transit visas even after he was forbidden to do so by his superiors from the Japanese Foreign Ministry. Thus the war influenced his later life as a diplomat, not always in a beneficial way. However, today Consul Sugihara is considered a hero and is commemorated in many ways, both in his native Japan and in Lithuania.

Keywords: Sugihara Chiune, Kaunas, Jews, Japan, World War II 